\title{
Instructional Model Cognitive Strategies Based to Enhance Higher Order Thinking of the Students with Cognitive Expressing Difficulties
}

\author{
${ }^{1}$ Martini Jamaris \\ Gedung M. Hatta PPs UNJ. Komplek UNJ. \\ Graduate Programs of State Univesity of Jakarta \\ Jl. RawamangunMuka. Jakarta 13220. Indonesia \\ martinijamaris@unj.ac.id
}

\begin{abstract}
This research aimed to find out instructional model cognitive strategies based leaded to increase the higher order thinking abilities of the students with cognitive expressing difficulties. The reason to do this research is because the emptiness of the research findings dealing with the instructional model cognitive strategies based to enhance higher order thinking of the students with cognitive expressing difficulties. Consequently, the rapid change at higher education teaching and learning approach will not be able to follow by the students with cognitive expressing difficulties. Furthermore, the condition will prevent the students to reach educational goals, as far as, they can achieve. Mix method research is conducted in the form of action research which involves quantitative research method aimed to get to know the increase of the students' higher order thinking and qualitative research method leaded to get information of the instructional process which applied to develop the students' higher order thinking. the research sample are 40 undergraduate students. qualitative research data analysis are analyzed in order to identified the existing of conceptual frameworks underlined the case studies' problems solving, critical thinking, productive thinking and creative thinking, as well as, cognitive strategies based instructional approach used during learning and teaching process. qualitative data analysis come out with cognitive strategies instructional model for increasing higher order thinking of the students with cognitive expressing difficulties. quantitative research data analysis revealed that the higher order thinking abilities of the students are increased in average $228.28 \%$ after participating the cognitive strategies based instructional approach.
\end{abstract}

Keywords: cognitive strategies 1; instructional model 2; the higher order thinking 3; cognitive expressing disabilities 4; mix method research 5 .

\section{INTRODUCTION}

Cognitive is the inner process which happened in human brain during thinking[1]. In lined with this Gagne [2] mentioned that cognitive is related to the abilities of the people to do information processing and organized the information in order to have meaning and to be used to solve problems or to understand any conditions around them. However, some of people cannot do the activities well, due to their difficulties in doing cognitive activities to process the information. It is called as cognitive expressing difficulties. Cognitive expressing difficulties is one of the forms of learning disabilities [3] Therefore, the individuals concerned are not able to perform cognitive tasks, particularly, higher order thinking tasks. Cognitive expressing disabilities haveto be solved as soon as possible, because the difficulties create other difficulties in academic areas and in day to day life activities, as well as, future life [4]. Furthermore, Taylor and Brush in Jamaris [5] stated that learning disabilities are the causes of failure to improve the quality of life of the individuals concerned. Until the present, researches on cognitive and instruction have been done by some researches. Among them are Geary [6]who reports about role of cognitive theory in the study of learning disability in mathematics. Other researchers interested in cognitive tutoring induces widespread neuroplasticity and remediates brain function in children with mathematical learning disabilities[7], as well as, Pressley and Hmas[8] study about cognitive strategies instruction from basic research to classroom instruction. 
In lined with the researches which have been described previously, there are no any studies dealt with the instructional model cognitive strategies based leaded to enhance higher order thinking abilities of the students with cognitive expressing difficulties. Therefore, this research is a break through leaded to come out with novelty in field of cognitive based instruction for students with cognitive expressing difficulties at university.

Other reasons underlined the previous logical reasons are in the present, it is seen that with the facilities provided by technological developments and with the changes in the labor demand in the market, undergraduate education and postgraduate education given at universities are now in a rapid change [9]. Within the scope of this change, new concepts have occurred, and one of these concepts is learning spaces, which defines new learning environments [10].

Based on the previous reasons, the aims of this research are to find out the cognitive strategies based instruction model for empowering higher order thinking abilities of the students with cognitive expressing difficulties. In line with this, the research is also aimed to get scientific information of the effectiveness of the instructional model cognitive based strategies in improving the students higher order thinking abilities.

\section{LITERATURE REVIEW}

As a part of learning disabilities, cognitive expressing difficulties [11] present themselves in various forms of difficulties in memory retention and perception process which triggered cognitive process obstacles which manifested in the forms of inability in learning and in solving problems, as well as, difficulties in cognitive operation [12]. This difficulty is caused by minimal brain disfunction [13]. Difficulties in cognitive operating can be seen from the abilities in processing information, which involves receiving information, identified information, organizing information and taking action or solve problems in accordance to the result of organizing information. Therefore, the abilities in solving problem effectively are the result of the abilities in processing information well. Meanwhile, the abilities are triggered by the abilities in making connection between concept formations and concept associations which leaded to come out with meaning full information. These abilities influenced the process of higher order thinking which involved critical thinking, productive thinking and creative thinking [14]. In lined with this, concept formation are devided into two stages, as followed : rule egg process which include any concepts which are collected and arranged through inductive experiences process and egg-rule process which involves any concepts which are collected and arranged through deductive experience process[15]. Any difficulties in doing rule-egg and egg-rule process influencethe abilities in processing information and trigger thinking difficulies.

Cognitive strategies dealth with the process of arranging, monitoring and evaluating thinking procesto accomplish goal in solving problems [16] which ranged from lower order thinking process up to higher order thinking process. Therefore, cognitive strategies are tools to think effectively, because they contained task thinking structures. Furthermore, cognitive strategies are usefull tools to help students. Especially, the students with cognitive expressing difficulties to improve their thinking proccess, both lower order thinking and higher order thinking . Consequently, cognitive strategies based instruction supported thinking processes to empower the students to accomplish thier learning tasks[17].

Gagne [18] stated that cognitive strategies related to thinking activities structures which arranged from of intelectual hierarchies. Intelectual hierarchies are sistematically structured from lowerorder thinking operation up to higher order thinking operation. All the intellectual hierarchie include : stage one, descrimination is prerequisite for concrete concept, stage 2, concrete concept is prerequisite for defined concept, stage 3, defined concept is prerequiaite for rules, stage 4 , rules is prerequisite for higher order rules, stage 5 , higher order is prerequsite for stage 6 , problem solving [19] [20]

Higher order thinking abilities manifested in the form of abilities in doing analysis, synthesis and evaluating of receiving information, in order, to get the meaning of the information concerned for solving problems [21] [22]. Those abilities transform themselves into abilities to do critical thinking productive thinking and creative thinking. Hudgin [23] described that critical thinking is a form of higher order thinking which constructed based on the understanding of problems or statements, as well as, empirical facts. All of them can be identified from: exploring any related facts which

supported by any statements or any summaries, evaluating any statements, in order, to get to know relation or different among them, evaluating inductive process based policies, evaluating the conformation of the relation between statements and theories, evaluating the back ground underlined any circumstances which cause any problems [24]. 
Productive thinking the abilities dealt with exploring process aimed to change classification or to reconceptualized the meaning, ideas or solutions which influence the problem solving process[25]. Creative thinking concern with abilities in finding key of ideas which have not been known previously Creative thinking is a kind of higher order thinking which is supported by divergent thinking abilities. This kind of thinking characterized is by originality which involves abilities in creating any ideas which previously have not been existed, flexibility dealt with abilities in finding any relations among existing ideas aimed to have something new, elaboration includes the abilities to enlarge any existing ideas, fluencely is relating to the abilities in promoting the implication of the existing ideas [26]

Cognitive strategies based instruction is one of the instructional approaches, in which, it is emphasized on thinking abilities improvement through learning how to think [27]. In lined with this, instructional approach is a tool to make students able to direct and to manage their own thinking activities strategically, as well as, productive learning abilities. Furthermore, cognitive strategies instruction approach allows students to interact with the materials to be learn by manipulating them mentally, as in making mental images or relating new information to previously aqcuired concepts or skills or physically, such as, grouping items to be learned in meaningfull categories or taking notes on or making summaries of important information tobe remembered[28]. Therefore, cognitive strategies based instruction model is in lined with successful learning.

Research results state that cognitive strategies based instruction can be used to any students. It is because, the instructional approach strengthen memory retation, motivation, and positive attitude of the students toward learning. Furthermore, cognitive strategies direct student to improve their thinking abilities [29]

Cognitive strategies based instruction can be implement in the form of cognitive behavior modification (CBM), in which, it can be applied in various forms of cognitive strategies, among them are SQ3R which involves: $\mathrm{S}=$ survey, $\mathrm{Q}=$ question, $3 \mathrm{R}=$ read, review and resolve . SOLVESIT which consists of : $\mathrm{S}=$ say theproblem in your way, $\mathrm{O}=$ omit unnecessary detail, $\mathrm{L}=$ listen for the key vocabulary, $\mathrm{V}=$ vocabulary with suggest procedure to use, $\mathrm{E}=$ equation, write the problemas math equation, $\mathrm{S}=$ solve the equation, $\mathrm{I}-=$ indicate the answer, and $\mathrm{T}=$ test the answer against the original question [ 30 ]. Furthemore, cognitve strategies can be done by: applying PQARS which includes : $\mathrm{P}=$ preview, $\mathrm{Q}=$ question, $\mathrm{R}=\mathrm{read}, \mathrm{S}=$ summarize [31]. Anoher cognitive strategies which known as KWL which consists of : $\mathrm{K}=$ what I know, $\mathrm{W}=$ what I want to finds out dan $\mathrm{L}=$ what I learn.

Beside all the cognitive strategies based instruction which have been mention previously, the instructional approach can also be constructed by applying Gagne's intellectual hierarchies[32], in which , it structures thinking process sistematically from lower order thinking operation up to higher order thinking operation. Consequently, the cognitive based instructional model allows the implementation of expository instructional based approach which is leaded to enchanch the students' lower order thinking and inquiry, as well as, discovery instructional based approach which is aimed to develop the students' higher order thinking through inquiryprocess.

The abilities in doing inquiry is reflection of inductive based higher order thinking operation which implemented by trial and error [33]Furthermore, inquiry abilities are identified by various abilities, as followed, finding problems, promoting prediction based on exiting knowledge and skills, formulating hypothesis, checking the hypothesis, collecting is aimed to test the effectiveness of the hypothesis, deciding if the data can be proof to test the effectiveness of the hypothesis leaded to solve problems [34].

Based on the critical analysis of related theories and research results which have been described previously, it is necessary to do some research which are leaded to construct instructional model which are focused on cognitive strategies based instruction to empower thinking abilities 


\section{METHOD}

Based on research questions and research aims this study use mixmethodresearch which packed in the form of action research, especially, Martini Jamaris’Action Reearch Model [35], as shown in figure 1.

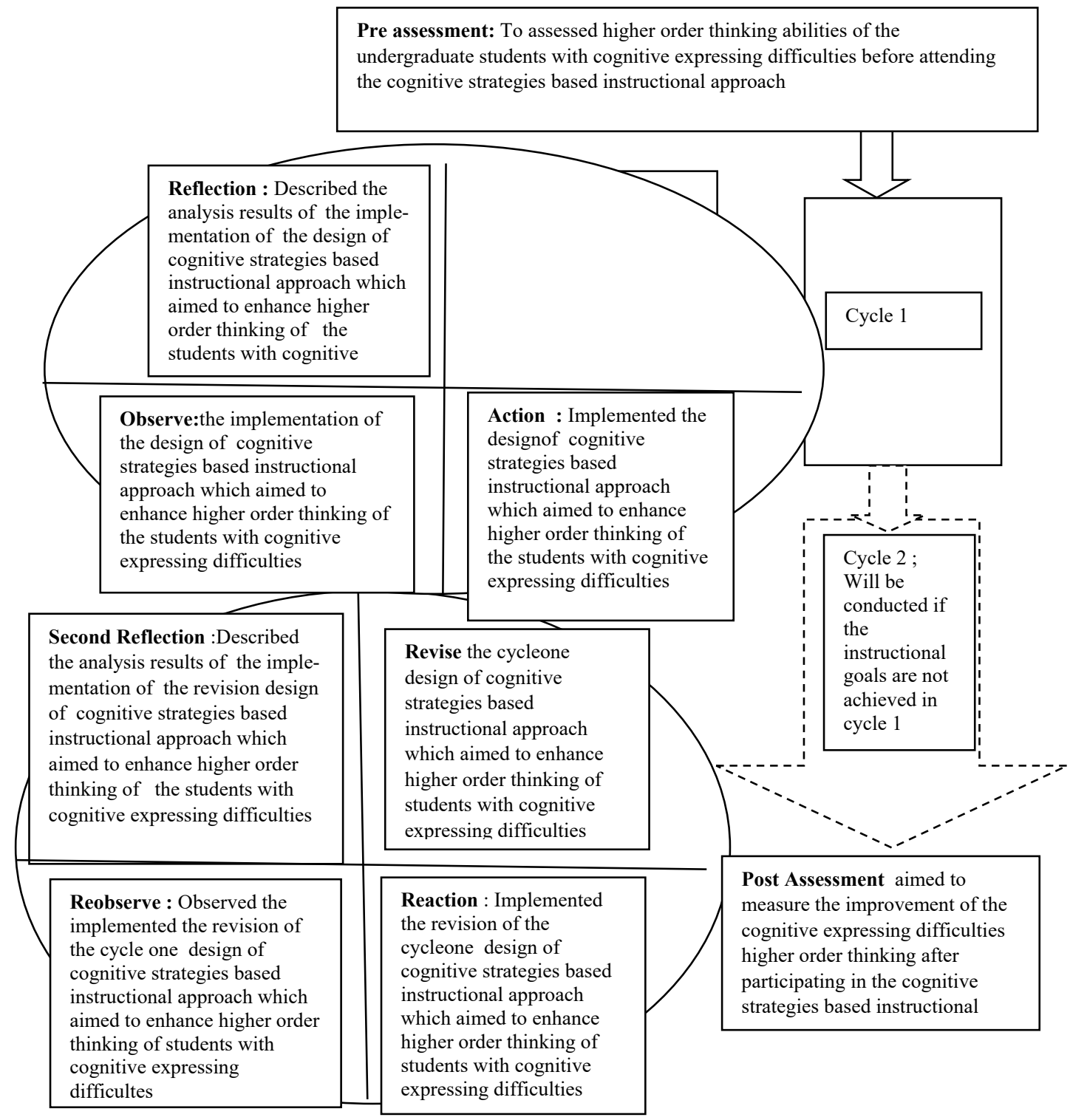

Figure 1. Martini Jamaris' Action Research Model

Research population are the students of State Univerisy of Jakarta. Sample of the research are selected by applying multistateges random sampling. Sample amount are 40 students who are decided based on the implementation of Copeoper\& Emory sample technique [36]. Due to the effectiveness of the research activities, consequently, the participants of the research are divided into five groups.

In accordance to the action research method used in this study, data analysis is conducted in the form of quantitative research data analysis and qualitative research data analysis. Therefore, to do effective data analysis, standard measured have been constructed for both data analysis, as described in table 1 .

To apply the standard measured, data collections are conducted in three layers, as followed, firstly, text of case study is given to the students, secondly, the students solve the case study's problems, thirdly, the students' answers in solving the case study's problems are analyzed in order to identified the existed of conceptual frameworks underlied the case study's problems, critical thinking, productive thinking and creative thinking, as well as, cognitive strategies based instructional approach used during learning and teaching process. 
In lined with the aims of the research, in which, one of them is to get to know the increase of higher order thinking of the students with cognitive expressing difficulties after attending cognitive strategies based instructional approach, therefore, standard measured to assess the improvement of the students' higher order thinking is constructed as shown in table 1.

The standard measured in table 1 are used to collect quantitative data through pre test, formative test and post test which leaded to have information about the increase of higher order thinking abilities the students with cognitive expressing difficulties before, during and after cognitive strategies based instructional approach.

Table 1: Standard Measured of Students' Higher Order Thinking

\begin{tabular}{|c|c|c|c|}
\hline No & Higher Order Thinking Classification & $\begin{array}{c}\text { Learning } \\
\text { Achievemen } \\
\mathrm{t}\end{array}$ & Skor \\
\hline 1 & $\begin{array}{c}\text { Excellent } \\
\text { (consistently exist accompanied with detail accurate } \\
\text { descriptions) }\end{array}$ & $81-100$ & 5 \\
\hline 2 & $\begin{array}{c}\text { Good } \\
\text { (consistently exist with accurate description) }\end{array}$ & $71-80$ & 4 \\
\hline 3 & $\begin{array}{c}\text { Average } \\
\text { (consistently exist with limited description) }\end{array}$ & $61-70$ & 2 \\
\hline 4 & $\begin{array}{c}\text { Bellow average } \\
\text { (exist with inaccurate description) }\end{array}$ & $51-60$ & 1 \\
\hline 5 & $\begin{array}{c}\text { Far bellow average } \\
\text { (inconsistently exist with inaccurate description) }\end{array}$ & & $21-50$ \\
\hline
\end{tabular}

Qualitative data analysis are conducted by using Spready qualitative data analysis which have been modified by Martini Jamaris[37]. as shown in table 2 .

Table2 . Qualitative Data Analysis

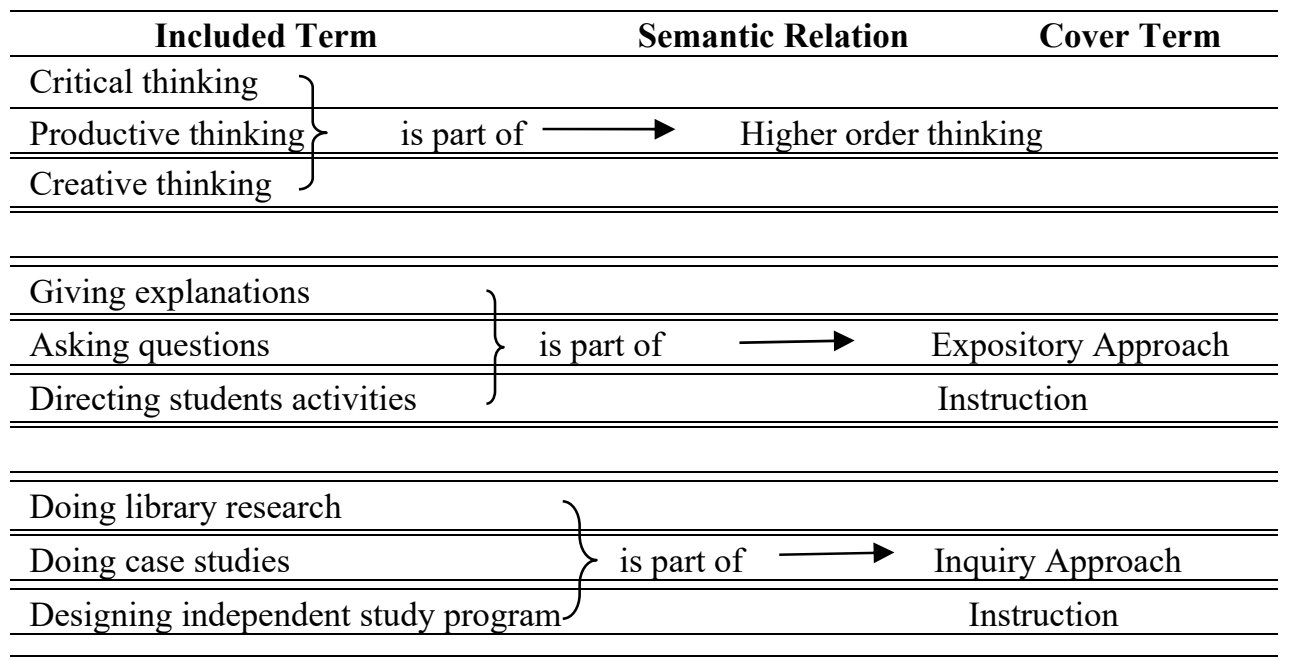

In collecting qualitative data, field notes sheet is constructed, in order, to record the various real instructional events leaded to fulfill the requirements of qualitative research. Consequently, coding system and the field notes is also developed, as described in table 3 and table 3, as followed:

Table 3: Research Data Coding

\begin{tabular}{|c|c|}
\hline Code & Data Categories \\
\hline Kkritis & Critical thinking abilities \\
\hline Kproduktif & Productive thinking abilities \\
\hline Kkreatif & Creative thinking abilities \\
\hline Expap & Expository Approach Instruction \\
\hline Inqap & Inquiry Approch Instruction \\
\hline
\end{tabular}


The implementation of field notes sheet during qualitative data collection are showed in the following table 4 .

Table 4. Field Notes Sheet of Data Collection

\begin{tabular}{|c|c|c|c|}
\hline Students' Statements & Researcher Reflection & $\begin{array}{l}\text { Cover } \\
\text { Terms }\end{array}$ & Codes \\
\hline $\begin{array}{l}\text { "In my opinion it is not learning } \\
\text { disabilities, because the cause of } \\
\text { unfocused in studying is feeling sad. } \\
\text { Learning disabilities is a condition } \\
\text { caused by minimal brain disfunction } \\
\text { manifested in information processing } \\
\text { disabilities. Furthermore, it caused } \\
\text { difficulties in doing academic tasks" }\end{array}$ & $\begin{array}{l}\text { Students's statements consist of his } \\
\text { abilities in showing supporting } \\
\text { evident concerning learning } \\
\text { disabilities }\end{array}$ & $\begin{array}{l}\text { Critical } \\
\text { thinking }\end{array}$ & Kkritis 01 \\
\hline $\begin{array}{l}\text { "In order to increase the students } \\
\text { abilities in processing information, } \\
\text { task analysis have to be designed and } \\
\text { conducted was related with } \\
\text { vocabularies development" }\end{array}$ & $\begin{array}{l}\text { Students's statements consist of his } \\
\text { abilities in critical thinking, } \\
\text { productive thinking, and creative } \\
\text { thinking, in which she showed her } \\
\text { abilities in promoting ideas and } \\
\text { solutions in solving case studies } \\
\text { problems }\end{array}$ & $\begin{array}{l}\text { Critical } \\
\text { thinking, } \\
\text { productive } \\
\text { thinking, } \\
\text { creative } \\
\text { thinking }\end{array}$ & $\begin{array}{l}\text { Kkritis } 02 \\
\text { Kprodutif } 02, \\
\text { Kkreatif } 02\end{array}$ \\
\hline
\end{tabular}

\section{RESULTS AND DISCUSSION}

In lined with the characteristics of mix method research, the research results are divided into two categories, firstly, quantitative research results which come out with the increase of higher order thinking of the students with cognitive expressing disabilities after participating cognitive strategies based instructional approach, secondly, qualitative research leaded to find out the cognitive strategies based instructional model for improving higher order thinking of the students with cognitive expressing disabilities, as shown in figure 2, in the previous page. instructional approach, secondly, qualitative research leaded to find out the cognitive strategies based instructional model for improving higher order thinking of the students with cognitive expressing disabilities, as shown in figure 2.Quantitative data analysis reveals that higher order thinking of the students with cognitive expressing difficulties increased after participating cognitive strategies based instructional approach. In detailed, the increase as shown in table 5 , as followed 


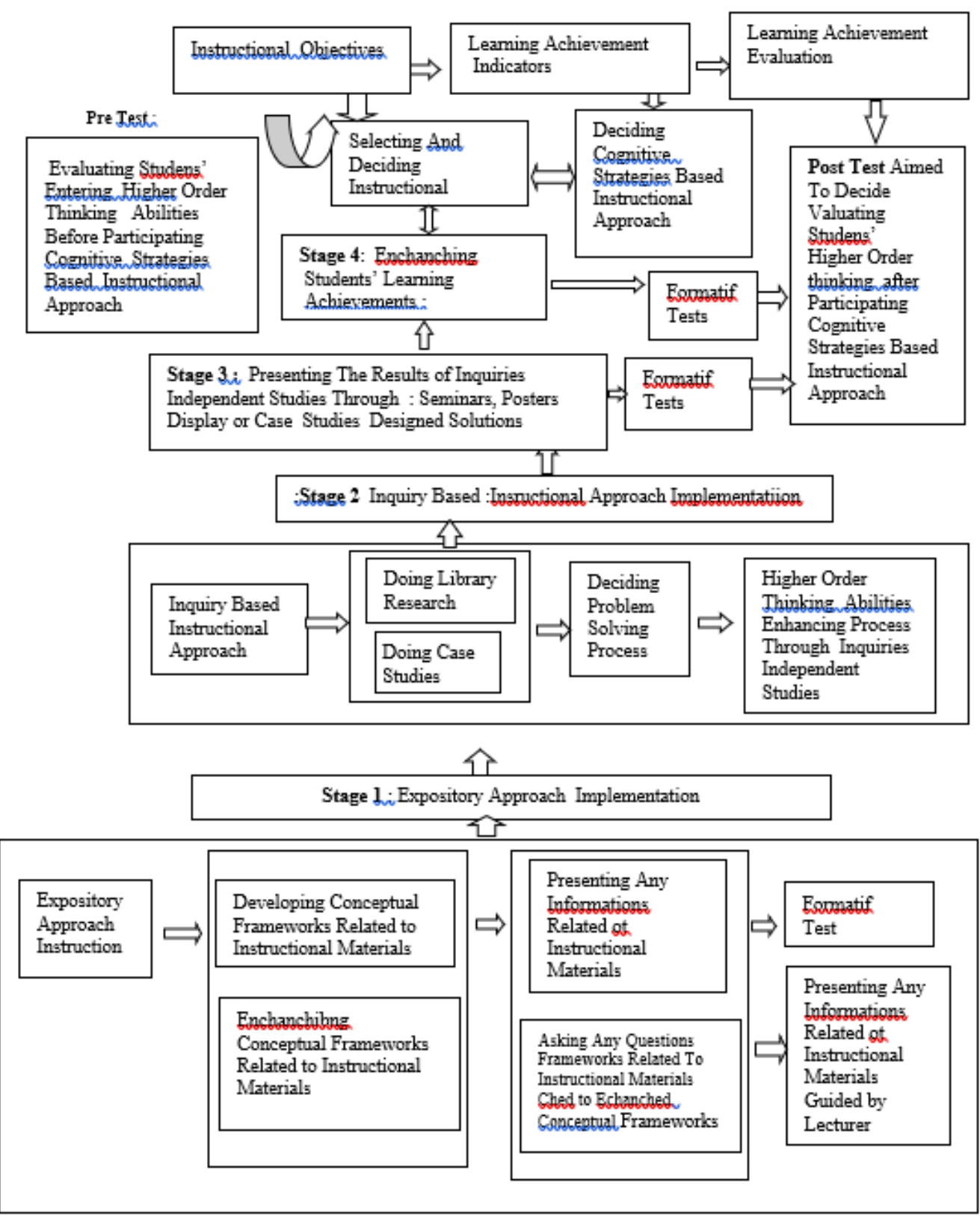

Figure 2i. Cognitive Strategies Based Instructional Model

Table 5 : The Improvement of Higher Order Thinking of The Students with Cognitive Expressing Difficulties

\begin{tabular}{|cccc|}
\hline Group & $\begin{array}{c}\text { Average Pre } \\
\text { Assessment Score }\end{array}$ & $\begin{array}{c}\text { Average Post } \\
\text { Assessment Score }\end{array}$ & $\begin{array}{c}\text { Average Score } \\
\text { Improvement }\end{array}$ \\
\hline 1 & 1.65 & 3.7 & $224.24 \%$ \\
\hline 2 & 1.65 & 3.9 & $236.36 \%$ \\
\hline 3 & 1.9 & 3.53 & $185.79 \%$ \\
\hline 4. & 2.0 & 3.9 & $195 \%$ \\
\hline 5 & 0.5 & 1.5 & $300 \%$ \\
$\begin{array}{c}\text { (consisted of 2 special } \\
\text { need students ) }\end{array}$ & & & $228.28 \%$ \\
\hline $\begin{array}{c}\text { Average Score } \\
\text { Improvement of the 5 } \\
\text { groups }\end{array}$ & & & \\
\hline
\end{tabular}




\section{DISCUSSION}

The research results implied that cognitive strategies based instructional model to enhance higher order thinking of the students with cognitive expressing difficulties come out with effective results. The effectiveness of instructional model is reflected from the improvement of students higher order thinking abilities. In lined with table 5 , the students higher order thinking improve about $228.28 \%$ in average. It is because the model accomodated the instructional strategies, starting from expository instructional approach aimed to enchanched conceptual framework of the students up to inquiry instructional approach leaded to empower higher order thinking ablities of the students with cognitive expressing difficuties.

As described in previous pages that the research come out with the instructional model cognitive strategies based to enhance higher order thinking of the students with cognitive expressing difficulties, in which, the model have never been found by previous researchers. Therefore, the research findings containted some novelties in the cognitive based instruction. Furthermore, it is regarded as a break through in the related field.

Based on the facts that until the present, there are no research reports about instructional model cognitive strategies based to enhance higher order thinking of the students with cognitive expressing difficulties. Consequently, it is difficult to compere the result of this research to other research results in related field. Therefore, the research results discussion are focussed on the relation of the research results to any related theories and the related research results which have been found previously.

The research findings[38] [39] [40]about theory of learning and thinkingand proved by Gagne [41],theory of cognitive strategies intellectual hierarchies, in which, he stated that instruction cognitive strategies based have to be arranged systematically [42] . In line with Gagne the instructional model, Greeno, Collins, \& Resnick van Dijk \&Kintsch[43]describe abouttheory of cognitive operation, as well as, cognitive theory of inquiry teaching, and Woolfolk \& McCune Nocilich's theory of concept formationAll of them supported the the research findings [44] [45][46][47].

The reasons underlied this rational description are the instructional model cognitive strategies based involved interactive components which consist of :assessing higher order thinking abilities of the students before participating the cognitive strategies based instructional approach, deciding instructional goals, deciding students' learning achievement, deciding instructional strategies, deciding instructional materials, deciding instructional evaluation, and deciding instructional feed back as shown in figure 2. All of them are the reflection of synthesized of the theories and research results which have been described previously.The research finding dealing with the intructional model which involves interactive componens are also supported by Suardana [48] and Wei Fang [49]

\section{CONCLUSION}

In accordance to the research results, it is concluded that cognitive strategies based instructional model is effective for improving higher order thinking of the students with cognitive expressing difficulties. It is proven by the improvements of higher order thinking of the students with cognitive expressing difficulties after participating cognitive strategies based instructional model.

\section{REFERENCES}

[1] Robert M. Gagne and Leslie J. Briggs . in Principles of Instruction Design, New York: Holt, Rineheart and Winston.p.71. 1979.

[2] Martini Jamaris. in Orientasi Baru Dalam Psikologi Pendidikan. Jakarta. Galia Indonesia.p 126. 2013

[3] Martini Jamaris. in KesulitanBelajar : Profil, Asesmen dan Pelayanan Pendidikan. Jakarta. Galia Indonesia. p 35. 2014

[4] D. Kim in Reid, in Teaching Learnig : A Cognitive Development Approach. Massachusett, Allyn \& Bacon, pp: 52-57. 1988

[5] Martini Jamaris. in KesulitanBelajar : Profil, Asesmen dan Pelayanan Pendidikan. Jakarta. Galia Indonesia. p 13. 2014

[6] David L.Geary. in Role of Cognitive Theory in the Study of Learning Disability in Mathematics. Journal of Learning Disabilities. July 1,2006

[7] Teresaluculano, Miriam Rosenberg Lee, Jenifer Richardson, Caitlin Tenison, Lynn Fuchs, Kautubn Supekar\& Vinod Menon.in Cognitive Tutoring Induces Widespread Neuroplasticity and Remediates Brain Fuction in Children with Mathematical Learning Disabilities. Nature Communication 6, article number 8453.2015

[8] Michael Pressley and Karen R. Hams inCognitive Strategies Instruction From Basic Research To Classroom Instruction. Journal of Education. December 4.2017

[9] A. Sonmez, L. Gocmez, D. Uygun, and M. Ataizi, cited by GurhanDurak, Serkan Cankaya, in The Current State of The Art in Learning Spaces:A Systematic Review, in International Journal of Emerging Techologies in Learning, Volume 13 Number 11, 2018.

[10] GurhanDurak, Serkan Cankaya, The Current State of The Art in Learning Spaces:A Systematic Review, in International Journal of Emerging Techologies in Learning, Volume 13 Number 11, 2018.

[11] Martini Jamaris.in KesulitanBelajar : Profil, Asesmen dan Pelayanan Pendidikan. Jakarta. Galia Indonesia. p 35.2014

[12] Martini Jamaris. in KesulitanBelajar : Profil, Asesmen dan Pelayanan Pendidikan. Jakarta. Galia Indonesia. p 5-6.2014

[13] Thomas C. Lovit. in Learning Disablities.Boston : Allyn \& Bacon. 7. 1989.

[14] Kirk A Samuell andJames J. Gallagher. in Educating Exceptional Children, Boston: Houghton Mifflin Company, pp. 356-410. 1992.

[15] Woolfolk Anita E \& McCune Nocilich Lorrain in Educational Psychology for Teachers. Englewood Cliff, New Jersey. Prentice-Hall, Inc. p. 204. 1984

[16] Greeno, J.G, Cpllon, A.M,\& Resnick. in Cognition and Learning. in D.C. Berliner, \&R.C Calfee (Eds). Henbook of Educational Psychology. pp 15-46. 1996

[17] Rosenshine, B. in 1997), in The Case for Explicit, Teabher-led, Cognitiv Strategy Instruction. Paper Presented at the Annual Meeting of the American Educational Research Assocition. Chicago. 1997 
[18] Gagne M. Robert, \& Briggs J. Leslie. in Principle of Instructional Design. New York. Rinehart and Winston. p. 62.1979

[19] Robert M. Gagne and Leslie J. Briggs. in Pirinciples of Instruction Design, New York: Holt, Rineheart and Winston. pp. .61-62. 1979.

[20] Heong Y.M., Othman, W.D,, Md Yunos., J. Kiong, T.T. Hassan R \& Mohamad ,MM. in The Level of Marzano Higher Order Thinking Seducation Skills among Technical Education Students.International Journal of of Social and Humanity. Vol 1, No 2. pp 121-125. July 2011

[21] Janet D. Donald. in Intellectual Skills in Higher Education. The Canadian Journal of Higher Education. Vol. XV-1, p 8. 1985

[22] Anderson, Richard. C . in Aquisation of Cognitive Skills. Psychological Review. Vol 13 No 8. p. 389-403. 1994

[23] Bryce B. Hudgins ( 1997) in Learning and Thinking. Itasca, Illinois: F.E. Peacock Publisher. p. 174. 1997

[24] I NyomanSuardana. in Students' Critical Skills in Chemistry Learning Using Cultura-Based 7E learning Cycle Model. International Journal of Instruction . Vol 11, No 2. pp 399-412. 2018

[25] Wertheimer. in HerbertJ. Klausmeieir\& William Goodwin. in Learning and Human Abilitrs. New York. Harper \& Row Publishers. p260. 1966.

[26] Bryce B.Hudgins. in earning and Thinking. Itasca, Illinois. F.E. Peacock Publishera. p 259. 1977

[27] Borkowski J., Carr. M., \& Pressly M. in Spontanious Strategy Use : Perspective from Metacognitive Theory. Intelligece. 11,p 61-75. 1987

[28] SimaKezrlou, in The Relation of Cognitive Strategies and Metacognitive Strategies, Age and Level of Education. http://www.adingmatrix.com/article/april 2012.

[29] D. Kim in Reid, in Teaching Learnig : A Cognitive Development Approach. Massachusett, Allyn \& Bacon, pp: 52-57. 1988

[30] Westwood Peter (1993).Methods for Children With Special Needs: Strategies for Regular Classroom, London: Roudledge

[31] Mc. Guines in Martini Jamaris. In AnakBerkebutuhanKhusus: Profil, Asesmen dan PelayananPendidikan. Jakarta. GaliaIndonesia. p 132-133. 2018

[32] Robert M. Gagne and Leslie J. Briggs (1971). Principles of Instruction Design, New York: Holt, Rineheart and Winston.p.71. 1979

[33] Robert Heinich, Michael Molenda \& James, D. Rusell ( 1990 )in Instructional Media and The News Technologies of Insructional. New York : MacMillan Publishing Company. p 10. 1990

[34] Allan Collin \& Albert I. Stevenson in Cognitive Theory of Inquiry Teaching “. Instructional Desain Theorie and Their Current Issues. New Jersey : Lawrence Erlbaum Associate Publisher.. p 260. 1993

[35] Martini Jamaris\&Edwita. in Formal Mutiple Intelligences Assessment Instrument for the 4-6 Years Old Children . American Journal of Educational Research .Vol. 2, No. 12, pp. 1164-1174. 2014 :

[36] CopeoperD.K\&Emory C.W. in Business Research Method . Ed. Burbidge. Illinois. p.231. 1995

[37] Martini Jamaris. in The Impact of the Graduate Students' Self -Evaluation to Their Academic Achievements. International of Multi diciplinary and Current Research, Vol 3. Issue 5. 242-249. May-June Issue, 2017

[38] Mario Mikulineer., Phillip R. Shaver., and Diana Pereq. in Attachment Theory and Effect Regulation : The Dynamics, Development, and Cognitive Concequences of Attachment-Related Strategie. Motivation and Emotion. Vol 27, No 2. June 2004

[39] Jeroen J.G van Merrienboer\& John Sweller. in Cognitive Load Theory in Helath Professional Education:Design and Principles and Strategies. Medical Education, 44, pp 85-93. 2010

[40] Marcel V.J. Veenman, Pascal Wilhem, Jos J. Beishuizen. in The Relation between Intellectual and Metocognitive Skills from a Developmental Perspectiv. Learning and Instruction 14. 89-109, 2004

[41] Robert M. Gagne and Leslie J. Briggs (1971). Principles of Instruction Design, New York: Holt, Rineheart and Winston. p 62. 1979

[42] Marcel V.J. Veenman, Pascal Wilhem, Jos J. Beishuizen. in The Relation between Intellectual and Metocognitive Skills from a Developmental Perspectiv. Learning and Instruction 14. 89-109, 2004

[43] Greeno, J. G., Collins, A. M., \& Resnick, L. in Cognition and learning. in Dole Janice A, Nokes Jeffery. D, \&Drits Dina. 2009. Cognitve Strategy Instruction.in Research Gate, p 4. 1996

[44] Michael Pressley and Karen R. Hams in Cognitive Strategies Instruction From Basic Research To Classroom Instruction. Journal of Education. December 4.2017

[45] Woolfolk Anita E \& McCune Nocilich Lorrain in Educational Psychology for Teachers. Englewood Cliff, NewJersey. Prentice-Hall, Inc. p. 204. 1984

[46] E. Sue Weber, in Cognitive Process Involved in Solving Information System(IS) Design Problem. Prociding in International Conference on Systems Information. 1985

[47] Heong Y.M., Othman, W.D,, Md Yunos., J. Kiong, T.T. Hassan R \& Mohamad ,MM. in The Level of Marzano Higher Order Thinking Seducation Skills among Technical Education Students.International Journal of of Social and Humanity. Vol 1, No 2. pp 121-125. July 2011

[48] I NyomanSuardana. in Students' Critical Skills in Chemistry Learning Using Cultura-Based 7E learning Cycle Model. International Journal of Instruction . Vol 11, No 2. pp 399-412. 2018

[49] Wei Fang. in Design of Heterogeneous Data Exchange Technology for Teaching Resources Based on ICMPv6. Intenational Journal of Emerging Technologies in Learning. Vol 13, No 11.2018 